\section{Fremragende om menneskets embryologi}

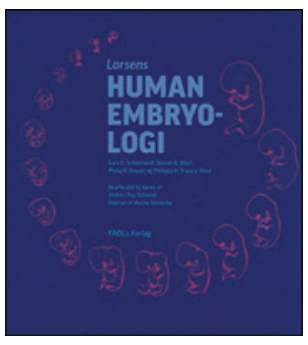

Gary C. Schoenwolf, Steven B. Bleyl,

Philip R. Brauer et al.

Larsens human embryologi

643 s, ill. København: FADL's Forlag, 2012.

Pris DKK 700

ISBN 978-87-7749-599-1

Boken er oversatt til dansk fra den fjerde utgaven av den klassiske Larsen's Human Embryology. Det er en lærebok hvor forfatterne behandler de viktigste og mest relevante kliniske aspektene av embryologi, og gir innsikt i nyere forskning. Målet er å formidle en forståelse for prinsippene i fosterets utvikling, som kan brukes i diagnose, behandling og forebygging av medfødte misdannelser.

Målgruppen er alle som er interessert i menneskets embryologi og tidlig utvikling av organer, men først og fremst medisinstudenter.

Av de 18 kapitlene omhandler seks generell embryologi, og ti spesiell embryologi. Alle kapitlene begynner med et oversiktlig sammendrag av innholdet. Forfatterne beskriver temaene klassisk, anatomisk embryologi, molekylære, embryologiske aspekter, inklusiv kunnskap fra forskningslaboratoriet, og klinisk relevans med patologiske, anatomiske aspekter. Det omfattende bildematerialet består av mikroskopiske bilder av embryoer og organer under utvikling, pent fargelagte tegninger som til dels gir et tredimensjonalt inntrykk av embryonale prosesser, og tabeller og bilder av individer med medfødte utviklingsavvik.

Det er viktig at embryologien blir levendegjort gjennom en sammenlikning med klinisk arbeid. Kunnskap om embryologiske prosesser kan ofte gi bedre innsikt i forståelsen av medfødte sykdommer som studenten senere møter i den kliniske hverdagen. I avsnittene kalt Fra klinikken gir man mange gode eksempler på slike kliniske tilstander og relasjonen til patoembryologiske prosesser, det vil si embryologiske utviklingsavvik, gjerne med forklaringer fra molekylærembryologien. I de forskjellige kapitlene finnes det også avsnitt med «kliniske smaksprøver». Det dreier seg om kasuistikker som illustrerer slike sammenhenger på en glimrende måte, noe som må være spesielt inspirerende for en medisinstudent som skal lære seg et veldig teoretisk fagområde.

Jeg etterlyser som ved alle andre embryologilærebøker, en sterkere tilknytning til sonoembryologien, et klinisk fagfelt som ble introdusert for 20 år siden. Leger bruker til daglig ultralyd for å vurdere meget tidlige svangerskap, og man har gjennom studier samlet erfaring med in vivo-embryologi (1). Det er for eksempel velkjent blant gynekologer at figur 6.6 på side 177 ikke er korrekt, chorionhulen oblitererer ikke mellom ukene fire til åtte, men først ca. én måned senere (2).

For tiden bruker man flere engelske lærebøker på norske universiteter, og Larsen's Human Embryology er en av dem. En dansk oversettelse gjør det enklere for norske studenter å tilegne seg fagstoff fra et vanskelig fagfelt. Larsens human embryologi er en fremragende embryologilærebok og meget godt egnet for den studerende.

\section{Harm-Gerd Karl Blaas}

Nasjonalt senter for fostermedisin

Institutt for laboratoriemedisin, barne- og kvinnesykdommer

Norges teknisk-naturvitenskapelige universitet

Litteratur

1. Blaas H-G, Eik-Nes SH, Berg S et al. In-vivo three-dimensional ultrasound reconstructions of embryos and early fetuses. Lancet 1998. 352:1182-6.

2. Blaas H-G, Eik-Nes SH, Bremnes JB. The growth of the human embryo. A longitudinal biometric assessment from 7 to 12 weeks of gestation. Ultrasound Obstet Gynecol 1998; 12: 346-54

\section{Oppdatert og god lærebok om kreft hos barn}

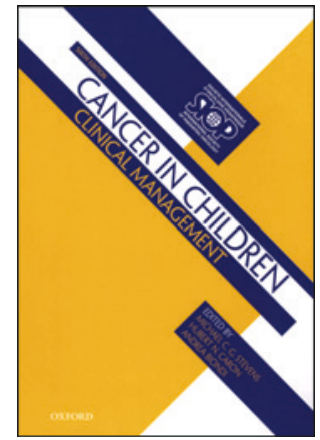

Michael C. G. Stevens, Hubert N. Caron,

Andrea Biondi, red.

Cancer in children

Clinical management. 6. utg. 400 s, tab, ill.

Oxford: Oxford University Press, 2012.

Pris GBP 85

ISBN 978-0-19-959941-7

Nå foreligger sjette utgave av denne læreboken som første gang ble publisert i 1975. Redaktørene har, som tidligere, knyttet til seg fagfolk som er eksperter innen sine fagområder, og som alle har gjort et omfattende arbeid for å oppdatere den nye utgaven. Spesielt er alle fremskritt som er gjort innen kreftbiologi, og vår forståelse av kreftstamceller, vekstregulering, genregulering og epigenetiske forandringer i relasjon til målrettet behandling, godt omtalt. Som i tidligere utgaver er alle aspekter av kreft hos barn godt beskrevet, og nyvinninger innen diagnostikk og behandling er inkludert. Når det er relevant, er flere behandlingstilnærminger omtalt.

Kapitlene er oversiktlige, og det er enkelt å finne frem. Teksten er kortfattet og presis og er derfor ikke så omfangsrik som i andre større lærebøker, men den er likevel like faktaorientert. Med en langtidsoverlevelse på nærmere $80 \%$ har oppfølging og senbivirkninger fått en sentral plass. Det faktum at det bare er $20 \%$ av verdens barn som har tilgang til behandling som gir $80 \%$ overlevelse, er også viet adekvat omtale. Her er også forholdene i middelog lavinntektsland, og hvordan man kan utvikle samarbeidsprogrammer for behandling og oppfølging i disse landene, beskrevet.

Layouten er tiltalende, boken er innbundet med hardcover, og papirkvaliteten er god. Figurene og tabellene er oversiktlige, og det er en oppdatert referanseliste til hvert kapittel.

Jeg kan anbefale boken på det varmeste til alle i målgruppen, som først og fremst er barneleger, onkologer, kirurger og nevrokirurger med ansvar for behandling av kreft hos barn, men også alt annet fagpersonell med interesse for kreft hos barn og som trenger en ny, oppdatert, oversiktlig lærebok eller ønsker et praktisk oppslagsverk.

\section{Finn Wesenberg}

Barnemedisinsk avdeling

Seksjon for blod og kreftsykdommer

Kvinne- og barneklinikken

Oslo universitetssykehus, Rikshospitalet 